\title{
THE POWER OF MONEY
}


This page intentionally left blank 


\section{THE \\ POWER OF MONEY}

Coinage and Politics in the

Athenian Empire

THOMAS FIGUEIRA

$\frac{\overline{\text { PENN }}}{\text { University of Pennsylvania Press }}$

Philadelphia 
Copyright $\odot 1998$ University of Pennsylvania Press

All rights reserved

Printed in the United States of America on acid-free paper

\section{1}

\section{Published by}

University of Pennsylvania Press

Philadelphia, Pennsylvania 19104-4011

Library of Congress Cataloging-in-Publication Data

Figueira, Thomas J.

The power of money: coinage and politics in the Athenian Empire / by Thomas Figueira.

p. $\quad \mathrm{cm}$.

Includes bibliographical references and indexes.

ISBN 0-8122-3441-3 (alk. paper)

1. Coinage-Political aspects-Greece-Athens-History.

2. Monetary policy-Greece-Athens-History. 3. Greece-History-Athenian supremacy, 479-431 в.c. 4. Athens (Greece)-Politics and government. I. Title.

CJ459.A8F54 1998

737'.4938'5-dc21 
This work is dedicated to the memory of Dorothy Gentile Fields, my maternal aunt and godmother, whose love helped sustain me through forty-five years of my life. Born in New York City of immigrant parents, Dolly did not have the opportunity to attend college during the Depression years. Exploiting her natural wit and a civility and urbanity that were once the hallmark of the true Manhattanite, she enjoyed a varied, successful career in entertainment and the media (along with raising two sons). At different times, she pioneered in the earliest days of live television, was a TV casting director, represented actors as a talent agent, was a producer in radio, produced a play off-Broadway, worked on Broadway, and wrote plays and scripts. Her grace, glamor, and supple humor enchanted one little boy, born in a furnished room in Washington Heights, whom she once carried out of a smoky building into the night. 
This page intentionally left blank 